disease will be supported. Grants will usually be from $£ 1,000$ to $£ 3,000$ per annum, to cover all the financial requirements of the programme.

The Fund is also offering Research Fellowships, which will be open to medical graduates or those with equivalent scientific training, for full-time research on fundamental problems brosdly related to cardiovascular function and disease or for clinical investigations in these fields. Fellowships traken up in Australia or Now Zealand for work in an approved institution will range from $£ 1,800$ to $£ 2,000$ for the term of one year in the first instance. Travelling Fellowships will be granted for a period of two years abroad, followed by a third year in an approved institution in Australia or New Zealand. The award will range from $£ 2,000$ to $£ 2,250$ per annum, and approved travelling expenses will also be allowed. Further information and application forms (to be returned before July 1) can be obtained from Dr. John H. Halliday, Medical Director, Life Insurance Medical Research Fund of Australia and New Zealand, 87 Pitt Street, Sydney, New South Wales.

\section{Grants for Graduate Research}

A REvised edition of the "Notes on D.S.I.R. Grants for Graduate Students and Research Workers" (pp. 22. London: H.M. Stationery Office, 1958. 1s. $6 d$. net) gives details of the awards which, under the new arrangements, the Postgraduate Training Grants Committee and the Research Grants Committee are prepared to recommend to the Research Council of the Department of Scientific and Industrial Research. The studentships of the former Committee comprise research studentships (formerly known as maintenance allowances) for postgraduate training in methods of research; advanced course studentships (a new award) for advanced courses of postgraduate instruction in science and technology; and Department of Scientific and Industrial Research fellowships, formerly known as senior research awards, for outstanding young investigators already trained in methods of research. The Reseirch Grants Committee recommends grants for special research, to help investigators of acknowledged standing to initiate and develop promising investigations. The awards do not include the research fellowships in Government establishments awarded annually on the recommendation of the Civil Service Commission.

As a result of recommendations made by the Willis Jackson Committee on the Supply and Training of Teschers for Technical Colleges, the number of places available for students who wish to train to become technical teachers is to be increased by more than 60 per cent and substantially higher rates of grants will be paid to students, though full details of the new scales of grants will not be known before completion of the triennial review of the standard figures of maintenance for students at universities and of training college grants now in progress. The final settlement will include increased personal grants to students, together with travelling expenses. It is expected that the technical colleges will need to recruit more than 2,000 new full-time teachers a year.

\section{Royal Society of Tasmania : Officers}

THE following were recently elected to office in the Royal Society of Tesmania : President, The Rt. Hon. Sir Ronald Cross, Governor of Tasmania; VicePresidents, Mr. J. W. C. Wyett and Mr. L. W. Miller ; Council, Mr. C. Bisdee, Mr. Justice Crisp, Dr. W. E. L. H. Crowther, Mr. R. M. H. Gervie, Dr.
E. R. Guiler and Mr. K. D. Nicholls; Hon. Treasurer, Mr. G. E. A. Hale; Hon. Auditor, Mr. A. M. Hewer; Hon. Secretary and Librarian, Dr. W. Bryden; Librarian, Miss E. M. Geddes.

\section{Announcements}

Dr. Vivian Fuchs, leader of the Commonwealth Trans-Antarctic Expedition, has been elected a member of the Athenæum under the provisions of Rule 2 of the Club, which empowers the annual election by the Committee of a certain number of persons of distinguished eminence in science, literature or the arts, or for their public services.

As indicated in recent annual reports, the Carnegie Institution of Washington is withdrawing from the field of Middle American archæology. On July 1, 1958, the offices of the Department of Archæology, at 10 Frisbie Place, Cambridge, Massachusetts, will close, and the Department will cease to exist. After that date all correspondence concerned with the past activities of the Department should be addressed to Carmegie Institution of Washington, $1530 \mathrm{P}$ Street, N.W., Washington 5, D.C.

The Food and Agriculture Organization of the United Nations has announced that it will offer eight to ten André Mayer Fellowships in 1958. These Fellowships will be awarded only to persons with the highest qualifications for research work in agriculture, agricultural economics and statistics, fisheries, forestry and nutrition. Further information can be obtained from the Secretariat of the F.A.O. National Committee for the United Kingdom, c/o Ministry of Agriculture, Fisheries and Food, Whitehall Place (East Block), London, S.W.1.

THE World Congress of Gastroenterology will be held in the Sheraton Park Hotel, Washington, D.C., during May 25-31. Further information can be obtained from Dr. H. M. Pollard, secretary-general of the Congress, University Hospital, Ann Arbor, Michigan.

THe Thames Valley Section of the Royal Institute of Chemistry is holding a symposium on "Radiation Chemistry of Organic Systems", by courtesy of the U.K. Atomic Energy Authority at Cockeroft Hall, Harwell, on May 9. Papers will be reviews rather than specialized accounts of original research. Further information can be obtained from Dr. E. S. Lane, Chemistry Division, Building 429, Atomic Energy Research Establishment, Harwell.

THE next standard Reactor School Course at Har. well, on which places are available, will commence on September 1 and finish on December 23. The first six weeks of the course will be held jointly at Birmingham, Bradford and Salford Colleges of Advanced Technology, and the remaining part at the Harwell Reactor School commencing on October 15. The fee for the course, which is open to British and overseas students, is £250. Selection of successful applicants will be made on June 2. Further informa. tion can be obtained from The Principal, Harwell Reactor School, Atomic Energy Research Establishment, Harwell, Berkshire.

Erratum. In the communication entitled "Effect of Gibberellic Acid on Fruit Set and Berry Enlargement in Seedless Grapes of Vitis vinifera" by Dr. Robert J. Weaver in Nature, March 22, p. 851, a mistake has occurred in Table 1 ; the average weights of clusters given in col. 2 are in 'pounds', not 'grams' as printed. 